\title{
BIOSYNTHESIS OF $\triangle$-AMINOLEVULINATE IN GREENING BARLEY LEAVES. VIII: PURIFICATION AND CHARACTERIZATION OF THE GLUTAMATE-tRNA LIGASE
}

\author{
by \\ PHILIPPE BRUYANT and C. GAMINI KANNANGARA \\ Department of Physiology, Carlsberg Laboratory, \\ Gamle Carlsberg Vej 10, DK-2500 Copenhagen Valby
}

Keywords: Chlorophyll biosynthesis, amino acid-tRNA synthetase, anti-ligase

Barley chloroplast glutamate-tRNA ligase was purified using salicylate-Sepharose and phosphocellulose chromatography. The purified enzyme amino-acylates $\delta$-ALA-RNA, the other glutamate acceptor tRNAs of the chloroplast, as well as E. coli tRNA Gilu. An antibody was raised against the purified ligase and coupled to Sepharose. The enzyme purified by immunoaffinity chromatography has a subunit molecular weight of 54 kilodaltons. The dehydrogenase involved in $\delta$-aminolevulinate synthesis was separated from the ligase by immunoaffinity chromatography. Reconstitution experiments confirmed that glutamate-tRNA ligase participates in $\delta$ aminolevulinate synthesis and it is suggested that a single glutamate-tRNA ligase provides activated glutamate for both chlorophyll and protein biosynthesis. An antibody raised against B. subtilis glutamate-tRNA ligase cross reacted with the barley glutamate-tRNA ligase.

\section{INTRODUCTION}

The control of chlorophyll synthesis is achieved primarily by regulation of $\delta$ aminolevulinate synthesis. In greening barley and other plants $\delta$-aminolevulinate is synthesised from glutamate by an unusual pathway. The first step in the pathway activates glutamate by ligating it to $\delta$-ALA-RNA. This step is catalysed by the enzyme glutamate-tRNA ligase in the presence of ATP and $\mathrm{Mg}^{2+}$. Glutamyl- $\delta$ ALA-RNA is then reduced to glutamate 1-semialdehyde by an NADPH-dependent dehydrogenase. Finally aminotransferase converts the semialdehyde to $\delta$-aminolevulinate. The enzyme glutamate 1-semialdehyde aminotransferase and the $\delta$-ALA-RNA have been purified and characterised $(5,6,15)$. In this paper we report the purification and characterisation of glutamate-tRNA ligase from the stroma of barley chloroplasts.

The dehydrogenase involved in $\delta$-aminolevulinate synthesis co-purifies with the glutamatetRNA ligase during affinity chromatography on Cibacron blue-Sepharose. Previous attempts to separate these two activities resulted in complete loss of the dehydrogenase activity. This paper

Abbreviations: $\delta$-ALA-RNA $=$ RNA involved in $\delta$-aminolevulinate biosynthesis; HEPES $=$ N-2-hydroxyethylpiperazine N'-2-ethanesulfonic acid; $1 \mathrm{M}_{\mathrm{c}}$-RNA = total tRNA fraction of greening chloroplasts isolated as described in (6); SDS = Sodium dodecyl sulfate; Tris = trihydroxymethyl aminomethane; TCA = trichloroacetic acid. 
also describes an immunoaffinity chromatography technique using an antibody raised against the purified ligase to separate it from the dehydrogenase without loss of activity of the latter.

\section{MATERIALS AND METHODS}

\subsection{The starting material for purification}

Intact chloroplasts were isolated from leaves of barley seedlings grown for six days in darkness and then illuminated for 12 hours. The plastids were disrupted by passing them through a French pressure cell and the soluble protein fraction was obtained by centrifugation. Thereafter the soluble proteins were subjected to Sephacryl S-300 gel filtration followed by affinity chromatography using Cibacron blueSepharose. The protein fraction that binds to the blue-Sepharose was eluted with salt and desalted using Sephadex G-50 gel filtration. The experimental details are as given in $(6,18)$. This protein fraction contained the glutamate-tRNA ligase and the dehydrogenase involved in $\delta$ aminolevulinate synthesis (6) and was used as starting material for the purification.

\subsection{Preparation of salicylate-Sepharose 4B}

Salicylic acid was coupled via its carboxyl group to the primary amino group of $\mathrm{AH}$ Sepharose 4B using N'-ethyl-N'-(3-dimethyl aminopropyl) carbodiimide according to the instructions provided by Pharmacia Fine Chemicals in their hand book "Affinity Chromatography principles and methods". After coupling, excess salicylate was removed by three successive washes with $0.1 \mathrm{M}$-Tricine- $\mathrm{NaOH} \mathrm{pH} 9.0$ containing $0.3 \mathrm{M}$-glycerol, $25 \mathrm{mM}-\mathrm{MgCl}_{2}, 1 \mathrm{mM}$ dithiothreitol and with $0.1 \mathrm{M}$-sodium acetate $\mathrm{pH}$ 4.5 containing $0.5 \mathrm{M}-\mathrm{NaCl}$.

\subsection{Salicylate-Sepharose chromatography}

A column $(1.5 \times 9 \mathrm{~cm})$ was packed with salicylate-Sepharose 4B using $0.1 \mathrm{M}$-sodium acetate pH 4.5 containing $0.5 \mathrm{M}-\mathrm{NaCl}$. The column was equilibrated with $0.1 \mathrm{M}$-Tricine- $\mathrm{NaOH} \mathrm{pH} 9.0$, $0.3 \mathrm{M}$-glycerol, $25 \mathrm{~mm}-\mathrm{MgCl}_{2}$ and $1 \mathrm{~mm}$-dithiothreitol. The protein fraction purified by chro- matography on blue-Sepharose was applied to this column and eluted with the above Tricine medium. The eluate was scanned for ultra-violet light absorption and collected in $2 \mathrm{ml}$ fractions. After the unadsorbed ultra-violet light absorbing materials were eluted, a $150 \mathrm{ml}$ linear gradient of 0 to $1 \mathrm{M}-\mathrm{NaCl}$ in the Tricine medium was applied to the column. Aliquots $(25 \mu \mathrm{l})$ from the fractions of the gradient were assayed in $1 \mathrm{ml}$ reaction mixtures for glutamate-tRNA ligase activity. After chromatography the column was washed with two to three column volumes of 1 $\mathrm{M}-\mathrm{NaCl}$ followed by $0.1 \mathrm{M}$-sodium acetate $\mathrm{pH}$ 4.5 containing $0.5 \mathrm{M}-\mathrm{NaCl}$. The salicylateSepharose $4 B$ column was stored in this acetate buffer. Column packing and chromatography were performed in a cold room at $4{ }^{\circ} \mathrm{C}$.

\subsection{Phosphocellulose $P_{11}$ chromatography}

Phosphocellulose $P_{11}$ was equilibrated with 10 mM-HEPES (N-2-hydroxyethylpiperazine-N'2-ethanesulfonic acid)- $\mathrm{NaOH}, \mathrm{pH} 7.2$ containing $0.3 \mathrm{M}$-glycerol, $1 \mathrm{mM}-\mathrm{MgCl}_{2}$ and $2 \mathrm{mM}$ dithiothreitol according to the instructions provided by the manufacturer. A column $(1.5 \times 12$ $\mathrm{cm})$ was packed. The glutamate-tRNA ligase containing fraction (or fractions) from the salicylate-Sepharose affinity chromatography was passed through a Sephadex G-50 column equilibrated with the above HEPES medium and applied to the phosphocellulose column. The phosphocellulose column was washed with the HEPES medium until all the unabsorbed, ultraviolet light absorbing materials were removed. The bound proteins were eluted using either a linear gradient of 0 to $0.3 \mathrm{mM}-\mathrm{KCl}(150 \mathrm{ml})$ or a step gradient of $0.5 \mathrm{M}$ and $1.0 \mathrm{M}-\mathrm{KCl}$ in the HEPES medium. With the linear gradient, the eluate was collected in $2 \mathrm{ml}$ fractions, and with the step gradient the eluate showing ultra-violet light absorption was collected. Aliquots $(25 \mu \mathrm{l})$ from the fractions were assayed in $1 \mathrm{ml}$ reaction mixtures for glutamate-tRNA ligase activity. The ligase containing fractions of the eluate from the linear gradient were pooled and dialysed against $10 \mathrm{~mm}-\mathrm{HEPES}-\mathrm{NaOH}$, pH 7.2 containing $0.3 \mathrm{M}$-glycerol, $1 \mathrm{mM}-\mathrm{MgCl}_{2}$ and 2 mM-dithiothreitol. In the step gradient, the relevant fractions were desalted using a Sephadex 
G-50 column. The proteins were concentrated using an Amicon pressure dialysis cell and a PM30 filter. All operations, except for column packing and enzyme assays, were performed in a cold room at $4^{\circ} \mathrm{C}$.

\subsection{Gel electrophoresis}

Polyacrylamide gel electrophoresis was performed in slab gels 30 by $20 \mathrm{~cm}, 1 \mathrm{~mm}$ thick with $2.5 \mathrm{~cm}$ long stacking gels. Non-denaturing gel electrophoresis was carried out using $7.5 \%$ polyacrylamide and the Tris-glycine buffer system described in (4). Electrophoresis under denaturing conditions was performed in $12.5 \%$ polyacrylamide gels containing $0.1 \%$ sodium dodecyl sulphate in the Tris-borate system as described in (2).

\subsection{Immunological methods}

\subsubsection{Preparation of anti-glutamate- $R N A$ ligase $\mathrm{IgG}$}

An antibody was raised in rabbits against the glutamate-tRNA ligase purified up to the phosphocellulose cation exchange chromatography step. Immunization was performed by Dakopatts A/S, DK-2600 Glostrup, Denmark, in doses of $0.1 \mathrm{ml}$ containing $100 \mu \mathrm{g}$ of antigen emulsified with Freunds incomplete adjuvant. IgG were purified from the immune serum according to (16).

\subsubsection{Preparation of anti-glutamate-tRNA ligase-Sepharose}

Anti-glutamate-tRNA ligase IgG was transferred into a medium containing $0.1 \mathrm{M}-\mathrm{NaHCO}_{3}$ and $0.5 \mathrm{M}-\mathrm{NaCl}$ by passing through a Sephadex G-50 column equilibrated in this solution. CNBr activated Sepharose 4B (5 g) was swollen for $15 \mathrm{~min}$ in $1 \mathrm{mM}-\mathrm{HCl}$ and washed with 1 liter of $1 \mathrm{mM}-\mathrm{HCl}$ using a sintered glass funnel and a water aspirator. The gel was then washed with 50 $\mathrm{ml}$ of $0.1 \mathrm{M}-\mathrm{NaHCO}_{3}$ containing $0.5 \mathrm{M}-\mathrm{NaCl}$ and immediately transferred into a $100 \mathrm{ml}$ conical flask containing $80 \mathrm{mg}$ of anti-ligase IgG in $30 \mathrm{ml}$ of $0.1 \mathrm{M}-\mathrm{NaHCO}_{3}, 0.5 \mathrm{M}-\mathrm{NaCl}$. The mixture was gently shaken for two hours at room temperature. Thereafter $1 \mathrm{ml}$ of $1 \mathrm{M}$-glycine at
pH 8.0 was added and shaking continued for additional two hours. The gel was then washed four times successively with $0.1 \mathrm{M}-\mathrm{NaHCO}_{3}, 0.5$ $\mathrm{M}-\mathrm{NaCl}$ and $0.1 \mathrm{M}$-sodium acetate $\mathrm{pH} 4.5,0.5$ $\mathrm{M}-\mathrm{NaCl}$. The gel was stored in the acetate buffer at $4{ }^{\circ} \mathrm{C}$.

\subsubsection{Immunoaffinity chromatography}

Anti-glutamate-tRNA ligase IgG-Sepharose 4B was packed into a column 1.5 by $10 \mathrm{~cm}$ using a $0.1 \mathrm{M}$-sodium acetate buffer $\mathrm{pH} 4.5$ containing $0.5 \mathrm{M}-\mathrm{NaCl}$. The column was washed with approximately $200 \mathrm{ml}$ of $0.1 \mathrm{M}$-Tricine- $\mathrm{NaOH}$ pH 9.0, 0.3 M-glycerol, $1 \mathrm{~mm}$-dithiothreitol and $25 \mathrm{~mm}-\mathrm{MgCl}_{2}$. The blue-Sepharose bound protein fraction (cf. 2.1) was applied to the antibody column. The column was washed with the Tricine-glycerol medium to remove all the unbound proteins and glutamate-tRNA ligase was eluted with $4 \mathrm{M}-\mathrm{MgCl}_{2}$ dissolved in the same medium. The ligase containing fraction was transferred into $0.1 \mathrm{M}$-Tricine- $\mathrm{NaOH} \mathrm{pH} 9.0$, $0.3 \mathrm{M}$-glycerol, $1 \mathrm{mM}$-dithiothreitol and $25 \mathrm{mM}$ $\mathrm{MgCl}_{2}$ by passing through a Sephadex G-50 column pre-equilibrated in this medium. The protein was then concentrated in an Amicon pressure dialysis cell using a PM30 filter. All these procedures were carried out in a cold room at $4^{\circ} \mathrm{C}$.

\subsection{Glutamate-tRNA ligase assay and the assay for $\delta$-aminolevulinate synthesis}

The glutamate-tRNA ligase activity was measured by incubating either 0.2 or $1 \mathrm{ml}$ reaction mixtures for 20 minutes at $28^{\circ} \mathrm{C}$. The incubation mixture contained $25 \mathrm{mM}-\mathrm{HEPES}-\mathrm{NaOH}$ $\mathrm{pH} 6.8,1 \mathrm{~mm}$-dithiothreitol, $3 \mathrm{~mm}-\mathrm{MgCl}_{2}, 1$ mM-ATP, $5 \mu \mathrm{Ci}{ }^{3} \mathrm{H}(\mathrm{U})$-L-glutamate, 0.05 to 2 $\mathrm{OD}_{260}$ units of tRNA and 20 to $100 \mu \mathrm{g}$ of enzyme proteins. The reaction was stopped by placing the tubes on ice and adding 100\% TCA to a final concentration of $10 \%$. The precipitated material was transferred to glass fiber filter paper and washed thoroughly with 5\% TCA followed by $96 \%$ ethanol. The filter was then dried under an infra-red lamp and radioactivity determined by scintillation counting.

Assay for $\boldsymbol{\delta}$-aminolevulinate synthesis was performed as described previously (6). 


\subsection{Other methods}

Protein concentration was determined according to the method of LowRY et al. (11). Radioactivity was measured by liquid scintillation counting.

\subsection{Chemicals and Enzymes}

L-glutamate-U- ${ }^{14} \mathrm{C}(275 \mathrm{mCi} / \mathrm{mmole}), \mathrm{L}$ $\left(3,4-{ }^{3} \mathrm{H}\right)$-glutamate $(47.7 \mathrm{Ci} / \mathrm{mmole}), \quad$ L- $(2,3-$ $\left.{ }^{3} \mathrm{H}\right)$-arginine $(15 \mathrm{Ci} / \mathrm{mmole})$ and $\left(2-{ }^{3} \mathrm{H}\right)$-glycine (41.2 $\mathrm{Ci} / \mathrm{mmole})$ were obtained from NEN, USA. Phosphocellulose $P_{11}$ was obtained from Whatman, England. AH-Sepharose 4B and $\mathrm{CNBr}$ activated Sepharose $4 \mathrm{~B}$ were obtained from Pharmacia, Sweden. N-ethyl-N'-(3-dimethylaminopropyl)-carbodiimide hydrochloride was obtained from Fluka AG, Switzerland. Barley tRNA used for this study was isolated as described previously (6). The total chloroplast tRNA fraction prepared by this procedure is referred to as $1 \mathrm{M}_{\mathrm{c}}$-RNA. $\delta$-ALA-RNA and the other two glutamate isoacceptor tRNAs were obtained from $1 \mathrm{M}_{\mathrm{c}}$-RNA by HPLC fractionation as described previously (6). E. coli tRNA ${ }_{2}^{\text {Glu }}$ was obtained from Boehringer Mannheim, West Germany. E. coli and B. subtilis glutamatetRNA ligase were provided by Prof. JACQUES LAPOINTE, Laval University, Québec, Canada.

\section{RESULTS}

\subsection{Purification of the glutamate-tRNA ligase}

3.1.1. Salicylate-Sepharose chromatography

Approximatively half of the proteins that bind to blue-Sepharose also bind to the salicylateSepharose column. When the bound proteins

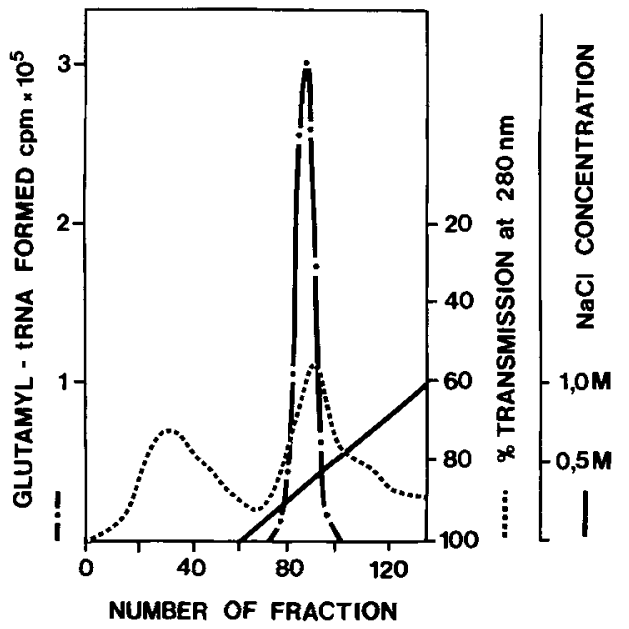

Figure 1. Salicylate-Sepharose affinity chromatography.

The bound proteins were eluted with a linear gradient from 0 to $1 \mathrm{M}-\mathrm{NaCl} .2 \mathrm{ml}$ fractions were collected. Alternate fractions $(25 \mu \mathrm{l})$ were tested for glutamatetRNA ligase acitivity in $1 \mathrm{ml}$ assays as described in 2.7 .

were eluted from the salicylate-Sepharose column using a gradient of $\mathrm{NaCl}$, glutamatetRNA ligase emerged as a single peak approximately at $0.25 \mathrm{M}-\mathrm{NaCl}$ (Figure 1). The peak fractions of activity gave a 4-5 fold purification of enzyme compared to the blue-Sepharose bound protein fraction. The active fractions were pooled and desalted. Several chromatographic runs were performed with the salicylateSepharose column by stepwise elution using 0.3 $\mathrm{M}-\mathrm{NaCl}$ and $1 \mathrm{M}-\mathrm{NaCl}$. All of the bound glutamate-tRNA ligase was eluted with $0.3 \mathrm{M}-\mathrm{NaCl}$.

Table I. Reconstitution of $\delta$-aminolevulinate synthesis using protein fractions separated by salicylate-Sepharose.

The $1 \mathrm{ml}$ control reaction mixture contained $100 \mathrm{~mm}$-Tricine $\mathrm{NaOH}, \mathrm{pH}$ 7.9, $0.3 \mathrm{M}$-glycerol, 1 mM-dithiothreitol, $25 \mathrm{mM}-\mathrm{MgCl}_{2}, 1 \mathrm{mM}-\mathrm{NADPH}, 0.5 \mathrm{mM}-\mathrm{ATP}, 5 \mathrm{mM}$-levulinate, $2.5 \mu \mathrm{Ci}$ of $\mathrm{L}-\left({ }^{14} \mathrm{C}-(\mathrm{U})\right) \mathrm{glutamate}(275 \mathrm{mCi} / \mathrm{mmole})$, $0.5 \mathrm{mg}$ of partially purified glutamate-1-semialdehyde aminotransferase and $2 \mathrm{OD}_{260}$ units of unfractionated RNA. $\delta$-aminolevulinate (cpm)

1. Control

2. $1+0.6 \mathrm{mg}$ blue-Sepharose bound proteins

3. $1+0.2 \mathrm{mg}$ salicylate-Sepharose bound proteins

4. $1+0.5 \mathrm{mg}$ salicylate-Sepharose bound and unbound proteins

$4,290,000$ 


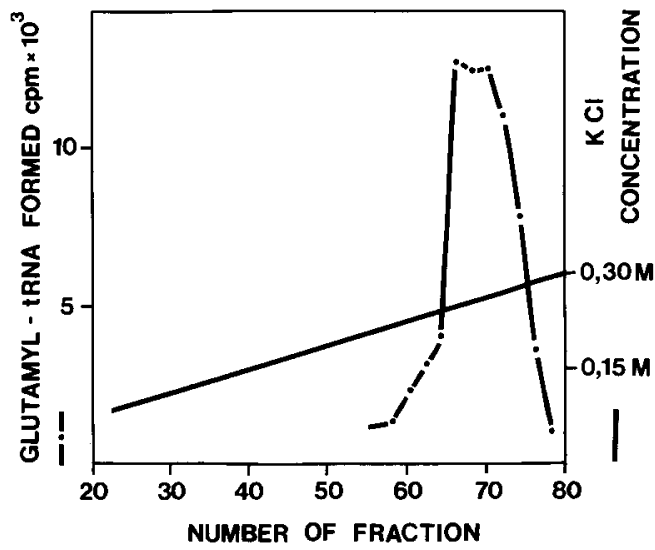

Figure 2. Phosphocellulose $P_{11}$ chromatography.

The ligase containing fractions from the salicylateSepharose chromatography were pooled, desalted and applied to the phosphocellulose column. After washing off the unbound proteins, the bound proteins were eluted with a linear gradient from 0 to $0.3 \mathrm{M}-\mathrm{KCl} .2 \mathrm{ml}$ fractions were collected. $25 \mu \mathrm{l}$ of alternate fractions were tested for glutamate-tRNA ligase acitivity in $1 \mathrm{ml}$ assays as described in 2.7 .

This fraction was desalted by passing through a Sephadex G-50 column and concentrated by pressure dialysis. Table I illustrates the ability of this fraction to reconstitute $\delta$-aminolevulinate synthesis with $\delta$-ALA-RNA and the aminotransferase containing fractions. The proteins that do not bind to the salicylate-Sepharose did not give a significant effect when added to the reconstituted assay mixture. It is concluded that the dehydrogenase involved in $\delta$-aminolevulinate synthesis binds to salicylate-Sepharose and co-elutes with the ligase under the conditions of chromatography used.

\subsubsection{Phospho-cellulose $P_{1 I}$ chromatography}

When the protein fraction obtained after salicylate affinity chromatography was chromatographed on the phosphocellulose column as described in section 2.4 more than $90 \%$ of the protein did not bind. However, the ligase bound to the phosphocellulose and was eluted as a single peak approximately at $0.25 \mathrm{M}-\mathrm{KCl}$ when a linear gradient of $\mathrm{KCl}$ was applied to the column (Figure 2). The phosphocellulose had a low capacity to adsorb ligase. It was necessary to apply the protein in a buffer of low ionic strength in order to have sufficient binding of the ligase. Increasing the concentration of HEPES from 10 $\mathrm{mM}$ to $25 \mathrm{mM}$ prevented the binding of the ligase to phosphocellulose. Even in the medium chosen, (10 mM-HEPES ( $\mathrm{N}-2$-hydroxyethyl-piperazine-N'-2-ethanesulfonic acid)- $\mathrm{NaOH}, \mathrm{pH} 7.2$ containing $0.3 \mathrm{M}$ glycerol, $1 \mathrm{mM}-\mathrm{MgCl}_{2}$ and 2 mM-dithiothreitol), the unbound fraction showed about $5 \%$ of the initial ligase activity. This was interpreted to be due to overloading of the column. When phosphocellulose chromatography was performed in $10 \mathrm{mM}-\mathrm{KPO}_{4}$ buffer $\mathrm{pH}$ 7.4, 0.3 M-glycerol, $1 \mathrm{mM}-\mathrm{MgCl}_{2}$ and 2 mM-dithiothreitol, ligase behaved exactly as in the HEPES system. However, the ligase lost its activity during pressure dialysis and it was concluded that ligase was not very stable in the phosphate buffer. Only a small fraction of the ligase bound to the phosphocellulose when chromatography was performed in $0.1 \mathrm{M}$-Tricine$\mathrm{NaOH}$ pH 7.4, 0.3 M-glycerol, $1 \mathrm{~mm}-\mathrm{MgCl}_{2}$ and 2 mM-dithiothreitol.

Attempts to reconstitute $\delta$-aminolevulinate formation with the bound and the unbound protein fractions from the phosphocellulose column were unsuccessful. It appears that phos-

Table II. Reconstitution of $\delta$-aminolevulinate synthesis using protein fractions separated by anti-glutamate-tRNA ligase Sepharose 4B.

The assays were performed as described in Table $I$.

Assay
Conversion of ${ }^{14} \mathrm{C}$-glutamate into $\delta$-aminolevulinate $(\mathrm{cpm})$
1. Control

2. $1+0.6 \mathrm{mg}$ blue-Sepharose bound proteins

3. $1+0.07 \mathrm{mg}$ anti-ligase bound protein

4. $1+0.5 \mathrm{mg}$ anti-ligase unbound proteins

5. $3+4$
16,700

$1,920,000$

20,300

49,100

$1,680,000$ 
Table III. The dehydrogenase involved in $\delta$-aminolevulinate synthesis binds to salicylate-Sepharose.

The blue-Sepharose bound proteins were chromatographed on anti-glutamate-tRNA ligase-Sepharose. The proteins that did not bind to this matrix were further chromatographed on the salicylate-Sepharose. The assays were performed as described in Table I.

Assay
Conversion of ${ }^{1+} \mathrm{C}$-glutamate into $\delta$-aminolevulinate $(\mathrm{cpm})$

1. $0.07 \mathrm{mg}$ anti-ligase bound protein

11,900

2. $1+0.3 \mathbf{m g}$ salicylate-Sepharose unbound proteins

15,900

3. $1+0.2 \mathrm{mg}$ salicylate-Sepharose bound proteins

$1,715,000$

4. $2+3$

phocellulose chromatography inactivates the dehydrogenase involved in $\delta$-aminolevulinate synthesis.

\subsubsection{Separation of the glutamate-tRNA ligase from the dehydrogenase by immunoaffinity chromatography}

The glutamate-tRNA ligase selectively bound to anti-ligase-Sepharose was eluted with $4 \mathrm{M}$ $\mathrm{MgCl}_{2}$. Table II illustrates the reconstitution of $\delta$-aminolevulinate synthesis using the protein fractions separated by immunoaffinity chromatography. The addition of glutamate-tRNA ligase alone to a reaction mixture containing the $\delta$-ALA-RNA and the aminotransferase containing fractions did not reconstitute $\delta$-aminolevulinate synthesis. Both the protein fraction that does not bind to anti-ligase-Sepharose as well as the glutamate-tRNA ligase that binds to this column were required for enzymatic conversion of glutamate to $\delta$-aminolevulinate. This observation confirms that glutamate-tRNA ligase participates in $\boldsymbol{\delta}$-aminolevulinate synthesis.

It is slear that the dehydrogenase involved in $\delta$-aminolevulinate synthesis does not bind to the anti-ligase-Sepharose. The proteins that did not bind to the anti-ligase-Sepharose were loaded onto the salicylate-Sepharose column and separated into bound and unbound protein fractions. The bound proteins were eluted with 0.3 $\mathrm{M}-\mathrm{NaCl}$, desalted and concentrated. Under these conditions the dehydrogenase involved in $\delta$-aminolevulinate synthesis bound to the salicylate-Sepharose column and remained fully active after elution (Table III).
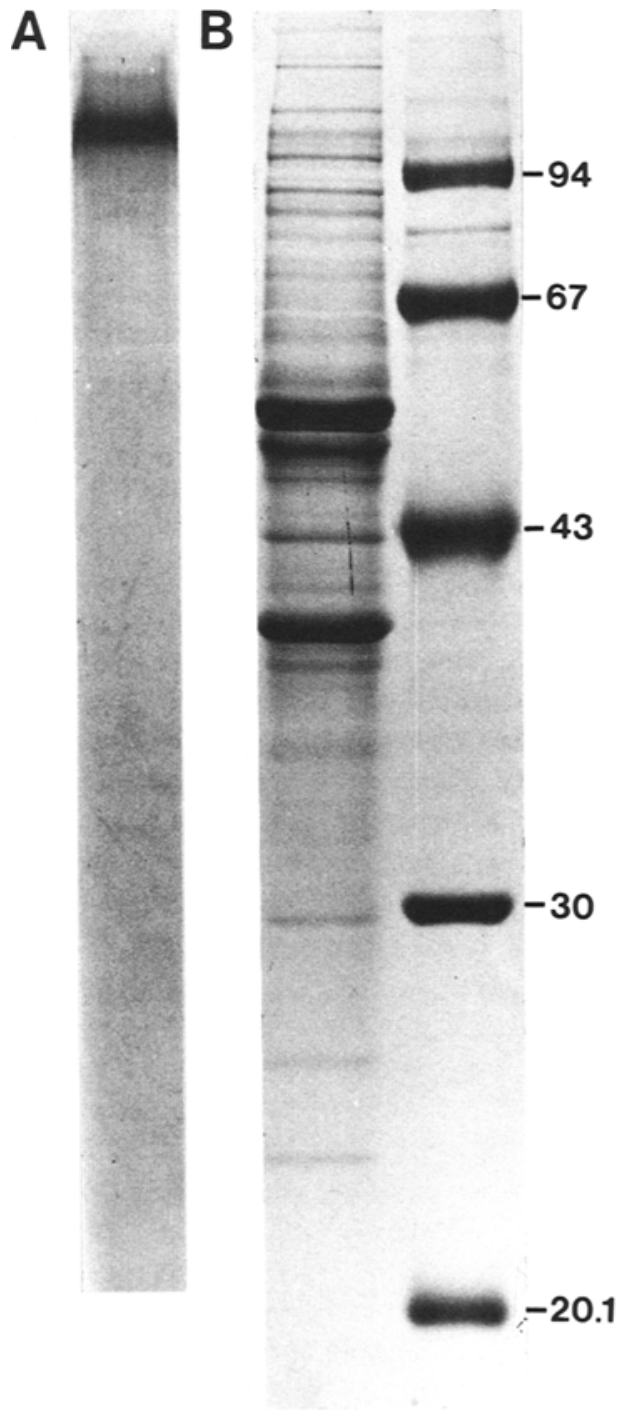


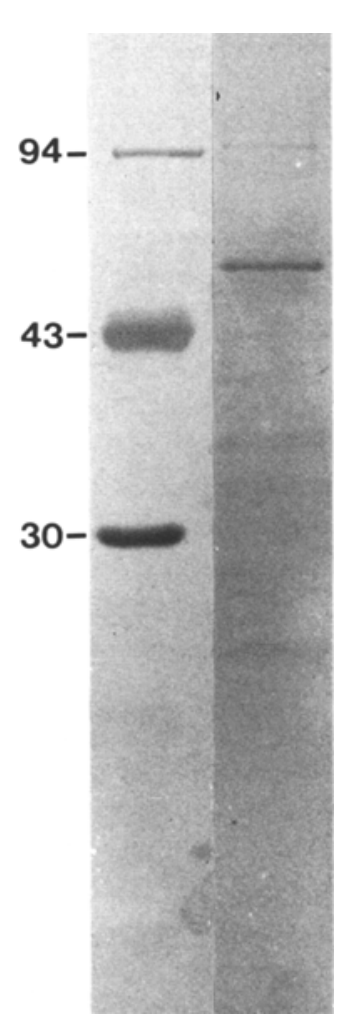

Figure 4. Polyacrylamide gel electrophoretic analysis of the ligase purified by immunoaffinity-Sepharose chromatography.

SDS-polyacrylamide gel electrophoresis. Silver staining. Molecular weight markers (left lane) are indicated in kilodaltons.

\subsubsection{Polyacrylamide gel electrophoresis}

The glutamate-tRNA ligase purified by salicylate-Sepharose and phosphocellulose gave a single, diffuse band upon non-denaturing polyacrylamide gel electrophoresis (Figure 3A). Under denaturing conditions it gave three bands

Figure 3. Polyacrylamide gel electrophoretic analysis of the ligase purified by phosphocellulose chromatography.

A. Electrophoresis in a $7.5 \%$ non-denaturing polyacrylamide gel.

B. SDS-polyacrylamide gel electrophoresis. Coomassie blue staining. Molecular weight markers (right lane) are indicated in kilodaltons. corresponding to apparent molecular weights of 53,50 and 39 kilodaltons and many faint bands (Figure 3B). These faint bands are considered to be contaminants and breakdown products. The glutamate-tRNA ligase purified by immunoaffinity chromatography gave one major band (Figure 4) corresponding to molecular weight of 54 kilodaltons and several faint bands in the ranges of 90-95 and 30-40 kilodaltons. We think that 53 to 54 kilodaltons represent the subunit molecular weight of barley chloroplast glutamate tRNA ligase and that the 50 and 39 kilodalton polypeptides in the phosphocellulose purified ligase are either contaminants not recognized by the antiserum or breakdown products of the 53 kilodalton polypeptide.

\subsection{Properties of the glutamate-tRNA ligase}

\subsubsection{Nucleotide requirement for the ligase activity}

ATP was required for the aminoacylation reaction catalysed by the ligase. The other nucleotide triphosphates or ADP could not replace ATP when analysed using the ligase purified up to the phophocellulose chromatography step (Table IV).

Table IV. The specificity of ATP in the aminoacylation with barley glutamate-tRNA ligase.

The reaction mixture contained in $1 \mathrm{ml}$ the following: 25 mM-HEPES, pH 6.8, 3 mM-MgCl 2,1 mM-dithiothreitol, $25 \mu \mathrm{Ci}$ of $\mathrm{L}-\left(3,4-{ }^{3} \mathrm{H}\right)$ glutamate $(47.7 \mathrm{Ci} /$ mmole), $50 \mu \mathrm{g}$ of purified glutamate-tRNA ligase, 0.25 $\mathrm{OD}_{260}$ unit of $\delta$-ALA-RNA and $1 \mathrm{~mm}$ of nucleotides.

Nucleotide added

${ }^{3} \mathrm{H}$-glutamyl-tRNA formation: TCA precipitable $\mathrm{cpm}$

\begin{tabular}{lr}
\hline none & 3,600 \\
ATP & 147,450 \\
ADP & 3,100 \\
CTP & 3,300 \\
GTP & 4,200 \\
\hline
\end{tabular}


Table V. The purified glutamate-tRNA ligase loads all three glutamate acceptor tRNAs present in barley chloroplasts.

The ligase purified by phosphocellulose chromatography was used in enzyme assays with $\delta$-ALA-RNA and the other two glutamate acceptor tRNAs purified by HPLC (6) as substrates.

\begin{tabular}{lrc}
\hline substrate & $\begin{array}{r}{ }^{3} \mathrm{H} \text {-glutamyl-tRNA formation: } \\
\text { TCA precipitable cpm }\end{array}$ \\
\hline 1. $\delta$-ALA-RNA & 301,800 \\
2. Glutamate acceptor tRNA 1 & 117,900 \\
3. Glutamate acceptor tRNA 2 & 172,900 \\
\hline
\end{tabular}

\subsubsection{The ability of glutamate-tRNA ligases} from barley chloroplast, $E$. coli and $B$. subtilis to aminoacylate different $t R N A_{S}^{G / u}$

The glutamate-tRNA ligase purified from barley chloroplasts aminoacylated the $\delta$-ALARNA and the two tRNAs of the chloroplast (Table V) as well as tRNA ${ }^{\text {Glu }}$ from E. coli (Table VI). The E. coli glutamate-tRNA ligase did not efficiently aminoacylate the chloroplast tRNA $A_{s}^{\text {Glu }}$. The B. subtilis glutamate-tRNA ligase was more efficient than E. coli glutamate-tRNA ligase in aminoacylating barley chloroplast tRNAS Glu (Table VI).

\subsubsection{Inhibition of the glutamate-tRNA ligase by anti-glutamate-tRNA ligase}

The polyclonal antibody obtained against the ligase inhibited the activity of this enzyme (Table VII). Ninety-two per cent inhibition was obtained when $114 \mu \mathrm{g}$ of anti-ligase $\mathrm{IgG}$ was included in the assay mixture containing $0.1 \mathrm{mg}$ of blue-Sepharose bound protein. The blue-

Table VI. tRNA substrate specificity of barley chloroplast, E. coli and B. subtilis glutamate-tRNA ligases.

The enzyme fractions were tested in $0.2 \mathrm{ml}$ assays as described in Material and Methods, 2.7. $\delta$-ALA-RNA refers to the RNA involved in $\delta$-aminolevulinate biosynthesis purified by HPLC from the total chloroplast tRNA fraction (1 $\mathrm{M}_{\mathrm{c}}$-RNA) isolated from greening barley chloroplasts as described in (6).

\begin{tabular}{|c|c|c|c|}
\hline & Enzyme & substrate & $\begin{array}{l}{ }^{3} \mathrm{H} \text {-glutamyl-tRNA formation: } \\
\text { TCA precipitable cpm }\end{array}$ \\
\hline 1. & E. coli ligase & E. coli tRNA & 69,000 \\
\hline 2. & “ & $1 \mathrm{M}_{\mathrm{c}}-\mathrm{RNA}$ & 3,140 \\
\hline 3. & “ & $\delta$-ALA-RNA & 1,070 \\
\hline 4. & Barley chloroplast ligase & E. coli tRNA & 435,600 \\
\hline 5. & “ & $1 \mathrm{M}_{\mathrm{c}}-\mathrm{RNA}$ & 635,900 \\
\hline 6. & “ & $\delta$-ALA-RNA & 629,500 \\
\hline 7. & B. subtilis ligase & $1 \mathrm{M}_{\mathrm{c}}-\mathrm{RNA}$ & 22,000 \\
\hline
\end{tabular}

Table VII. Inhibition of glutamate-tRNA ligase by the antibody against the enzyme.

The blue-Sepharose bound proteins $(0.1 \mathrm{mg})$ were pre-incubated at room temperature with different amounts of anti-ligase IgG and assayed for their ability to ligate glutamate, glycine and arginine to tRNA as described in section 2.7 using either $\mathrm{L}-\left(3,4-{ }^{3} \mathrm{H}\right)$-glutamate $(47.7 \mathrm{mCi} / \mathrm{mmole}), \mathrm{L}-\left(2,3-{ }^{3} \mathrm{H}\right)$-arginine $(15 \mathrm{Ci} / \mathrm{mmole})$ or $\mathrm{L}-\left(2-{ }^{3} \mathrm{H}\right)$-glycine (41.2 Ci/mmole).

\begin{tabular}{|c|c|c|c|}
\hline Pre-incubated with: & Amino acid & $\begin{array}{l}{ }^{3} \mathrm{H} \text {-glutamyl-tRNA formation } \\
\text { TCA precipitable cpm }\end{array}$ & $\begin{array}{l}\text { \% Inhibition } \\
\text { control }\end{array}$ \\
\hline None (control) & ${ }^{3} \mathrm{H}$-glutamate & 523,000 & 0 \\
\hline $57 \mu \mathrm{g}$ anti-ligase $\mathrm{IgG}$ & “ & 285,000 & 45 \\
\hline $114 \mu \mathrm{g}$ & $"$ & 37,000 & 93 \\
\hline $171 \mu \mathrm{g}$ & “ & 40,000 & 92 \\
\hline $228 \mu \mathrm{g}$ & “ & 9,900 & 98 \\
\hline None (control) & ${ }^{3} \mathrm{H}$-arginine & 228,000 & 0 \\
\hline $114 \mu \mathrm{g}$ anti-ligase IgG & “ & 232,000 & 0 \\
\hline None (control) & ${ }^{3} \mathrm{H}$-glycine & 39,100 & 0 \\
\hline $114 \mu \mathrm{g}$ anti-ligase IgG & “ & 30,800 & 21 \\
\hline
\end{tabular}


Table VIII. The antibody to barley chloroplast glutamate-tRNA ligase recognizes the B. subtilis glutamate-tRNA ligase.

The $0.2 \mathrm{ml}$ reaction mixture contains $100 \mathrm{~mm}-\mathrm{HEPES} \mathrm{pH} 7.2,10 \mathrm{mM}-\mathrm{KCl}, 10 \mathrm{~mm}-\mathrm{MgCl}_{2}, 2 \mathrm{~mm}-\mathrm{ATP}, 5 \mu \mathrm{Ci}$ of $\mathrm{L}-\left(3,4-{ }^{-3} \mathrm{H}\right)$ glutamate $(47,7 \mathrm{Ci} / \mathrm{mmole}), 10 \mu \mathrm{l}$ of partially purified $\mathrm{B}$. subtilis glutamate-tRNA ligase and $2 \mathrm{OD}_{260}$ of unfractionated barley chloroplast tRNAs. In assays 2 and 3,60 $\mu \mathrm{g}$ and $120 \mu \mathrm{g}$, respectively, of IgG were added. Incubation was for 40 minutes at $30{ }^{\circ} \mathrm{C}$.

\begin{tabular}{lcc}
\hline $\begin{array}{l}\text { Amount of anti-barley } \\
\text { glutamate-tRNA ligase added }\end{array}$ & $\begin{array}{l}\text { Amount of Glu-tRNA formed } \\
\text { (TCA precipitable cpm) }\end{array}$ & \% inhibition \\
\hline 1. $\quad 0 \mu \mathrm{g}$ IgG & 89,800 & 0 \\
2. $60 "$ " & 64,400 & 28 \\
$3.120 "$ & 29,600 & 67 \\
\hline
\end{tabular}

Sepharose bound protein fraction contains other amino acid-tRNA ligases (6). The anti-ligase $\operatorname{IgG}(114 \mu \mathrm{g})$ had no effect on the activity of the arginine-tRNA ligase and caused only $21 \%$ inhibition of glycine-tRNA ligase. The antibody against the barley glutamate-tRNA ligase also inhibited the B. subtilis ligase (Table VIII).

A polyclonal antibody to $B$. subtilis glutamate-tRNA ligase (provided by Prof. J. LAPOINTE) reacted with the barley chloroplast ligase and gave an immunoprecipitate. The enzyme, however, was not inactivated in the immunoprecipitate (Table IX).

\section{DISCUSSION}

The results presented in this paper confirm that glutamate-tRNA ligase catalyses the first step in the conversion of glutamate to $\delta$ aminolevulinate. The purification procedure applicable to the ligase and its enzymatic and physical properties show a close similarity to the glutamate-tRNA ligases involved in protein synthesis.

Salicylate is an inhibitor of amino acid-tRNA ligases and the most sensitive among these is the glutamate-tRNA ligase (1). Therefore salicylateSepharose was used for affinity purification of the barley chloroplast glutamate-tRNA ligase. Phosphocellulose $P_{11}$ chromatography has been used in the purification of glutamate and glutamine-tRNA ligases $(3,8,9,17)$. This was also an effective step in the purification of barley chloroplast glutamate-tRNA ligase. The wheat chloroplast and E. coli glutamate-tRNA ligases have been purified using hydroxyapatite and phosphocellulose chromatography $(8,17)$. The instability of the barley chloroplast enzyme in phosphate buffers prevented the use of hydroxyapatite columns which require phosphate anions for chromatographic separations.

The dehydrogenase involved in $\delta$-aminolevulinate synthesis was partially purified in its active form using immunoaffinity chromatography followed by salicylate-Sepharose chromatography. This is an easy and quick method to obtain starting material for further purification of the dehydrogenase. Since dehydrogenase activity is completely lost during phosphocellulose chromatography we suggest that the dehydrogenase activity is due to an enzymatic complex which

Table IX. The B. subtilis glutamate-tRNA ligase antibody immunoprecipitates the barley glutamate-tRNA ligase without inhibiting its activity.

$50 \mu \mathrm{g}$ of blue-Sepharose bound proteins were incubated with 0 (control), 2.5, 5 and $10 \mu \mathrm{g}$ of anti-B. subtilis glutamate-tRNA ligase IgG for 20 minutes at $28{ }^{\circ} \mathrm{C}$. The immunoprecipitate was collected by centrifugation and washed once with $20 \mu \mathrm{l}$ of $25 \mathrm{mM}-\mathrm{HEP}$ ES, pH 6.8 containing 1 mM-dithiothreitol and 3 $\mathrm{mM}-\mathrm{MgCl}_{2}$. The pellet was assayed for loading activity as described in material and methods.

\begin{tabular}{|c|c|}
\hline $\begin{array}{l}\text { Amount of anti- } \\
\text { B.subtilis glutamate- } \\
\text { tRNA ligase used } \\
\text { for pre-incubation }\end{array}$ & $\begin{array}{l}\text { Amount of barley gluta- } \\
\text { mate-tRNA } \\
\text { ligase precipitated } \\
\text { (TCA precipitable cpm) }\end{array}$ \\
\hline 0 (control) & 8,150 \\
\hline $2.5 \mu \mathrm{g} \mathrm{IgG}$ & 9,185 \\
\hline $5.0 \lll$ & 11,980 \\
\hline 10.0 & 62,000 \\
\hline
\end{tabular}


irreversibly dissociates during phosphocellulose chromatography.

Wheat chloroplast glutamate-tRNA ligase is a dimer of 110 kilodaltons which dissociates on dilution to inactive 56 kilodalton monomers $(14,17)$. In E. coli and B. subtilis glutamatetRNA ligases are monomers of 56 and 65 kilodaltons, respectively, $(7,8,13)$ which associate with a 46 kilodalton protein. The 46 kilodalton protein is considered to be a regulatory factor because it increases the affinity of the ligase for glutamate and $\operatorname{ATP}(8,13)$. The possibility of such a regulatory factor associated with the barley chloroplast glutamate-tRNA ligase cannot be excluded.

In the present study only one glutamate specific amino acid-tRNA ligase was identified in the stroma of greening barley chloroplasts. The purified enzyme aminoacylates $\delta$-ALARNA and the other two glutamate acceptor tRNAs present in the chloroplast. Therefore it is likely that in greening barley chloroplasts a single glutamate-tRNA ligase provides activated glutamate for both chlorophyll and protein biosynthesis and plays a significant role in the coordination of the two biosynthetic pathways.

The glutamate-tRNA ligase from barley chloroplasts aminoacylates both the procaryotic tRNA $^{\text {Glu }}$ from E. coli and the cytoplasmic eucaryotic tRNA ${ }^{\text {Glu }}$ from wheat germ. This indicates similarities between the cytoplasmic and chloroplast glutamate-tRNA ligases. These similarities may be the result of a single nuclear gene encoding both enzymes. In yeast a single nuclear gene encodes the histidine-tRNA synthetase destined for the cytoplasm as well as that imported into mitochodria, the latter being distinguished by a special transit peptide sequence (12).

Procaryotic glutamate-tRNA ligases were expected to aminoacylate chloroplast tRNAS since the components of chloroplast protein biosynthesis resemble those of procaryotes in many ways. Two bacterial glutamate-tRNA ligases were tested for their ability to aminoacylate barley chloroplast tRNA Glu. The enzyme from B. subtilis significantly aminoacylates the chloroplast tRNA $A_{s}^{\text {Glu }}$, but the enzyme from E. coli shows little if any activity in this respect. This adds to the exceptional lack of specificity which is displayed by the B. subtilis glutamatetRNA ligase for $t R N A^{G l u}$ and $t R N A^{G / n}$ substrates (cf. 10).

\section{ACKNOWLEDGEMENTS}

We thank Prof. Diter von Wettstein, Dr. SIMON P. GOUGH and Dr. SANDY BERRY-LowE for helpful discussions and critically reading of the manuscript. Mrs. NINA RasmuSSEN is thanked for drawing the figures and Mrs. ANNSOFI STEINHOLTZ is thanked for photography. Prof. JACQUES LAPOINTE is thanked for generously providing the bacterial enzymes and the antibody against the $B$. subtilis glutamate-tRNA ligase. This work was supported in part by a grant from the Danish Ministry of Education to PhilipPe BRUYANT.

\section{REFERENCES}

1. BURLEIGH, M. \& M.J. H. SMITH: The mechanism of the inhibitory action of salicylate on glutamyltransfer ribonucleic acid synthetase in vitro. J. Pharm. Pharmac. 23, 590-594 (1971)

2. ChuA, N. H. \& P. Bennoun: Thylakoid membrane polypeptides of Chlamydomonas reinhardtii: Wild-type and mutant deficient in photosystem II reaction center. Proc. Nat. Acad. Sci. USA. 72, 6, 2175-2179 (1975)

3. HaRa-Yokoyama, M., S. Yokoyama \& T. MiYazaWA: Purification and characterization of glutamyltRNA synthetase from an extreme thermophile, Thermus thermophilus HB 8. J. Biochem. 96, 1599-1607 (1984)

4. HedRICK, J.L. \& A. J. Smith: Size and charge isomer separation and estimation of molecular weights of proteins by disc gel electrophoresis. Arch. biochem. Biophys. 126, 155-164 (1968)

5. Kannangara, C. G., S. P. Gough \& C. Girnth: $\delta$-Aminolevulinate synthesis in greening barley. 2 . Purification of enzymes. In: 5th Int. Congr. Photosyn. V. Chloroplast Development. G. Akoyunoglou ed. Balaban International Science Services, Philadelphia, pp 117-127 (1981)

6. Kannangara, C. G., S. P. Gough, R. P. Oliver \& S. K. RASMUSSEN: Biosynthesis of $\boldsymbol{\delta}$-aminolevulinate in greening barley leaves VI. Activation of glutamate by ligation to RNA. Carlsberg Res. Commun. 49, $417-437$ (1984)

7. KERN, D.\& J. LAPOINTE: Glutamyl transfer ribonucleic acid synthetase of Escherichia coli. Study of 
the interactions with its substrates. Biochem. 18, 26, 5809-5818 (1979)

8. KERN, D., S. POTIER, Y. BOULANGER \& J. LAPOINTE: The monomeric glutamyl-tRNA synthetase of Escherichia coli. Purification and relation between its structural and catalytic properties. J. Biol. Chem. 254, 2, 518-524 (1979)

9. Kern, D., S. Potier, J. Lapointe \& Y. Boulanger: The glutaminyl-transfer RNA synthetase of Escherichia coli. Purification, structure and function relationship. Biochim. Biophys. Acta. 607, 65-80 (1980)

10. Lapointe J., L. Duplain \& M. Proulx: A single glutamyl-tRNA synthetase aminoacylates tRNA $^{\text {Glu }}$ and tRNA ${ }^{\text {Gln }}$ in Bacillus subtilis and efficiently misacylates Escherichia coli tRNA ${ }^{\text {Glu }}$ in vitro. J. Bacter. 165, 88-93 (1986)

11. LOWRY, O. H., N. J. ROSENBROUGH, A. L. FARR \& R. J. RANDALL: Protein measurement with Folin-phenol reagent. J. Biol. Chem. 193, 265-275 (1951)

12. Natsoulis, G., F. Hilger \& G. R. FinK: The HTS1 gene encodes both the cytoplasmic and mitochondrial histidine tRNA synthetase of S. cerevisiae. Cell, 46, 235-243 (1980)

13. Proulx, M., L. Duplain, L. Lacoste, M. Yaguchi \& J. LAPOINTE: The monomeric glutamyl-tRNA synthetase from Bacillus subtilis 168 and its regulatory factor. J. Biol. Chem. 258, 2, 753-759 (1983)

14. Ratinaud, M. H., J. C. Thomes \& R. Julien: Glutamyl-tRNA synthetases from wheat. Isolation and characterization of three dimeric enzymes. Eur. J. Biochem. 135, 471-477 (1983)

15. SChÖN, A., G. Krupp, S. Gough, S. BerRy.Lowe, C. G. KANNANGARA \& D. Söll: The RNA required in the first step of chlorophyll biosynthesis is a chloroplast glutamate tRNA. Nature 322, 281-284 (1986)

16. SChreiber, A. B. \& J. Haimovich: Quantitative fluorometric assay for detection and characterization of $F_{c}$ receptors. Methods of Enzymology vol. 93 ed. J. J. Langone and H. Van Vunakis. Acad Press. 147-155 (1983)

17. Thomes, J.C., M. H. Ratinaud \& R. Julien: Dimeric glutamyl-tRNA synthetases from wheat. Kinetic properties and functional structures. Eur. J. Biochem. 135, 479-484 (1983)

18. WANG, W-Y., S. P. Gough \& C. G. KanNangaRa: Biosynthesis of $\delta$-aminolevulinate in greening barley leaves IV. Isolation of three soluble enzymes required for the conversion of glutamate to $\delta$ aminolevulinate. Carlsberg Res. Commun. 46, 243-257 (1981) 